\title{
Neuro-Behçet's disease: a clinical and radiological dilemma
}

\author{
Zainab Al-Maqrashi, Abdullah M Al Alawi
}

Medicine, Sultan Qaboos University Hospital, Muscat, Oman

Correspondence to Dr Abdullah M Al Alawi; dr.abdullahalalawi@gmail.com

Accepted 27 August 2020

\section{DESCRIPTION}

Behçet's disease (BD) is a clinical syndrome characterised by systemic vasculitis commonly involving the central nervous system. ${ }^{1}$ However, brain stem involvement is less pronounced. ${ }^{2}$ The lack of definitive conclusive tests with prime dependence on clinical criteria led to low applicability and diagnostic ambiguity in challenging cases of isolated organ involvement or atypical presentation. ${ }^{34}$

We report a 44-year-old man who presented to the emergency department with 1-day history of undocumented febrile illness, drowsiness, nausea and headache. In further exploration of his presenting complaint, collateral history of mental and behavioural changes was prompted manifesting as paranoia, social withdrawal and memory disturbances over 2 months. Detailed assessment for proceeding head trauma, exposure history and substance misuse was unremarkable as well as thorough systemic review. Clinically, patient appeared apathic and hypophonic with delayed verbal responses. Meningeal signs were elicited coupled with craniopathy (bilateral trigeminal, facial and bulbar involvement), subtle cerebellar dysfunction plus generalised hypotonia and brisk reflexes and distal muscle weakness primarily of lower limbs. Head-to-toe examination otherwise was unremarkable including funduscopic assessment.

Initial metabolic (electrolytes, serum osmolality, glucose, thyroid function, cortisol, angiotensinconverting enzyme), infectious (HIV, hepatitis, syphilis and Brucella serologies), serum electrophoresis and autoimmune (antinuclear antibody, rheumatoid factor, anti-neutrophilic cytoplasmic autoantibodies) screens were non-diagnostic. He underwent lumbar puncture twice during his admission, cerebrospinal fluid examination showed leucocytes $157 /$ cumm (normal 0 to 10 ) with $95 \%$ polymorphs, erythrocytes 44/cumm (normal 0), protein $1.62 \mathrm{~g} / \mathrm{L}$ (normal 0.15 to 0.45 ) and glucose $5.7 \mathrm{mmol} / \mathrm{L}$ (normal 2.2 to 3.9 ) and unremarkable microbiology, cytology, limbic, paraneoplastic and oligoclonal bands' screens. A non-contrast CT scan of head did not show any acute insult; however, MRI revealed abnormal signal intensity involving brain stem, internal capsule and bilateral cerebellar peduncle (figure 1). Review of performed electroencephalogram demonstrated evidence of mild-moderate diffuse encephalopathy with no epileptiform discharges or lateralising signs.

In his journey to recovery, he was initially treated in line of aseptic pyogenic meningoencephalitis. Where his meningism and acute complaints marginally improved, the consolation of other subacute

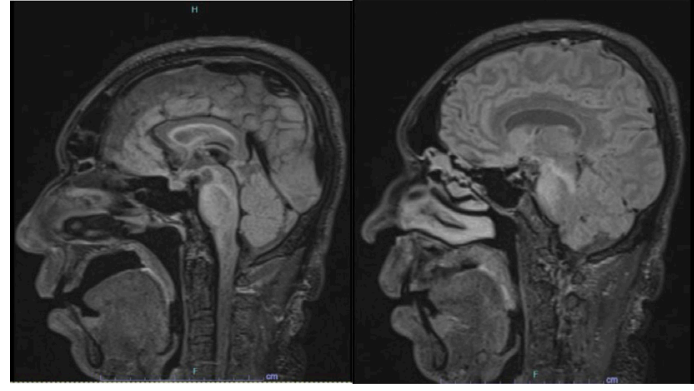

Figure 1 Extensive brain stem hyperintensity involving midbrain, pons, medulla with extension to toward the internal capsule.

neurological symptomology and deficits did not. After multidisciplinary case review with general medicine, diagnostic radiology, infectious diseases, rheumatology and neurology specialists; patient was started on 5-day course of pulse steroids and intravenous immunoglobulin in view of high suspicion for probable neuro-Behçet's disease. By day 10 of admission, marked clinical and radiological response (figure 2) was observed.

On discharge, patient was partially ambulatory with minimal assistance and near normalisation of his overall status. Patient sustained follow-up on outpatient basis with rheumatology and neurology services and currently on maintenance mycophenolate mofetil while tapering prednisolone therapy.

Behçet's disease is unique model of systemic vasculitis with multiorgan involvement. The diagnosis is ascertained clinically in majority of cases. This case represented diagnostic challenge for a patient with BD's neurological involvement in the absence systemic disease. The lesion mainly involved the brain stem carrying risk of haemodynamic-respiratory deterioration; thus, it

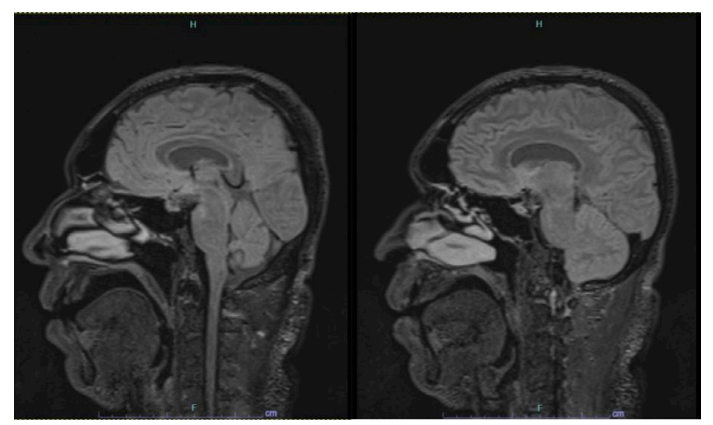

Figure 2 An interval improvement of the brain stem hyperintensity. 
was crucial to reach a diagnosis and initiate the treatment in a timely manner.

\section{Learning points}

Behçet's disease could present with isolated and critical neurological manifestations warranting prompt diagnosis and treatment.

- In the presence of undifferentiated heterogeneous complex medical presentation, a multidisciplinary team approach offers diagnostic superiority over fragmented care.

Acknowledgements We would like to thank our colleagues in the Department of Medicine at Sultan Qaboos University for their valuable contributions to caring for our patient. In particular, we highly appreciate the expertise of Dr Abdullah Al-Asmi (Neurology Unit), Prof Arunodaya R Gujjar (Neurology Unit), Dr Ibrahim Al Busaidi (Infectious Disease Unit), Dr Ali Al Shirawi (Rheumatology Unit), Dr Talal Al Lawati (Rheumatology Unit), Dr Ahmed Al-Qassabi (Neurology Unit), and Dr Sunil Lekhwani (Neurology Unit).
Contributors ZA-M consented the patient and contributed in writing the manuscript; AMAA proposed the idea of submitting the image, did the literature review and drafted the first version of the manuscript; AMAA reviewed the radiological images and edited the figure; ZA-M and AMAA finalised the manuscript.

Funding The authors have not declared a specific grant for this research from any funding agency in the public, commercial or not-for-profit sectors.

Competing interests None declared.

Patient consent for publication Obtained.

Provenance and peer review Not commissioned; externally peer reviewed.

\section{ORCID iD}

Abdullah M Al Alawi http://orcid.org/0000-0003-2077-7186

\section{REFERENCES}

1 Mohamed C, Najib K, Essaadouni L. Radiological findings in Behçet disease. Pan Afr Med J 2015;20:51.

2 Mohan MC, Koya JM, Kandaswamy GVP, et al. Neuro-Behcet's: a diagnostic challenge. Oxf Med Case Reports 2015;2015:311-3.

3 Fabiani G, de Almeida SM, Germiniani FM, et al. Neuro-Behçet: report of three clinically distinct cases. Arq Neuropsiquiatr 2001;59:250-4.

4 Ho CL, Deruytter MJ. Manifestations of neuro-Behcet's disease. Report of two cases and review of the literature. Clin Neurol Neurosurg 2005;107:310-4.

Copyright 2020 BMJ Publishing Group. All rights reserved. For permission to reuse any of this content visit

https://www.bmj.com/company/products-services/rights-and-licensing/permissions/

BMJ Case Report Fellows may re-use this article for personal use and teaching without any further permission.

Become a Fellow of BMJ Case Reports today and you can:

- Submit as many cases as you like

- Enjoy fast sympathetic peer review and rapid publication of accepted articles

- Access all the published articles

- Re-use any of the published material for personal use and teaching without further permission

Customer Service

If you have any further queries about your subscription, please contact our customer services team on +44 (0) 2071111105 or via email at support@bmj.com.

Visit casereports.bmj.com for more articles like this and to become a Fellow 